\title{
LOS MORTEROS CENTROITÁLICOS DE SEGOBRIGA
}

\author{
THE ITALIAN MORTARS OF SEGOBRIGA
}

\author{
ROSARIO CEBRIÁN FERNÁNDEZ \\ Parque Arqueológico de Segóbriga \\ IGNACIO HORTELANO UCEDA \\ Equipo Técnico de Segóbriga
}

Entre los materiales cerámicos hallados en las excavaciones arqueológicas en Segobriga se encuentran una serie de morteros de procedencia centroitálica del que sólo dos ejemplares han sido dados a conocer en trabajos anteriores. El primero de ellos es un mortero Dramont D 2 hallado en 1982 en el anfiteatro, que presenta sello epigráfico con mención del artesano Quietius, esclavo de Statius Marcius Celer, officinator, que trabajó antes del 79 d. C. (Sánchez 1990, 122-123, fig. 3; Aguarod, 1991, 147, fig. X, h; Pallecchi, 2002, 209). El segundo se localizó en 1987 en la excavación de la puerta principal de acceso a la ciudad desde el norte, donde se nombra a Priscus, esclavo de Cn. Domitius Lucanus y Cn. Domitius Tullus (Almagro-Gorbea y Lorrio, 1989, 153 y fig. 77, $n^{\circ} .2$ ).

Los hallazgos de morteros de origen centroitálico en Hispania se concentran principalmente en ciudades costeras o con puertos fluviales, por lo que su presencia elevada en Segobriga confirma la importancia de la ruta terrestre que unió el interior peninsular con el área del sureste, con caput viae en Carthago Nova (Abascal y Cebrián 2007, 257-262).

Los trabajos ya clásicos de J. P. Joncheray sobre el cargamento del pecio Cap Dramont D (Joncheray, 1972, 1973 y 1974), de M. y R. Sabrié sobre los morteros procedentes del pecio C del Grand Bassin, en Gruissan (Sabrié y Sabrié, 1981) y de K. F. Hartley acerca de la comercialización de morteros, tejas y otros materiales itálicos hacia el extremo noroccidental del Imperio (Hartley, 1973a y b) continúan siendo, pese a los años transcurridos desde su publicación, los estudios de referencia en cuanto a su producción y rutas de difusión. De la misma manera, en Hispania, el capítulo dedicado a los morteros itálicos en el estudio de C. Aguarod (1991) sobre las cerámicas importadas de cocina de la Tarraconense, constituye el principal trabajo de síntesis, limitándose el resto de la bibliografía a repertorios de piezas y estudios epigráficos sobre sus sellos (Martínez y Sáiz, 1977; Pérez y Fernández, 1989; Sánchez, 1990; Rocas y Roviras, 1995; Arruda y Viegas, 2004).
El origen principal de la producción se establece, basándose en la uniformidad de las pastas usadas en su fabricación y en la correspondencia entre los sellos de los morteros y del material latericio, en talleres ubicados en el centro de Italia, más concretamente en la periferia de Roma y en las riberas de la zona navegable del Tíber y de sus afluentes (Aguarod, 1991, 132 y 152-153). Su comercialización, estudiada principalmente por K. F. Hartley (1973a y b), se relaciona con el transporte fluvial y marítimo, ya sea en asociación con otros productos fabricados en las mismas figlinae, como materiales de construcción y dolia, o bien formando parte de la carga principal del navío. Mientras que en el primer caso las mercancías constituirían cargamentos de retorno de los mercantes en su vuelta a sus puertos de origen (Hartley, 1973b, 50-52; Aguarod, 1991, 179), en el segundo formarían una parte secundaria del cargamento principal, que podría estar compuesto por ánforas vinarias u olearias, como en el pecio castellonense de Ben-Afelí (Fernández Izquierdo, 1980, 173-184; Ramos et alii, 1985, 149-158), por aceite, vajilla de mesa y lucernas, como en el pecio catalán de Cala Culip IV (Nieto et alii, 1989), por fruta desecada, como en el provenzal de Cap Dramont D (Joncheray, 1973, 40), o por lucernas, como en el languedociano del Grand Bassin C en Gruissan (Sabrié y Sabrié, 1981).

La difusión espacial de los hallazgos de estos morteros, principalmente de la variante Dramont D 2, pone de relieve la existencia de unas redes de distribución que se extienden desde sus centros de producción a orillas del Tíber al resto del Imperio, relacionándose por lo general con las grandes vías de penetración fluvial, como el Ródano, Rin, Ebro o Guadalquivir. Abarca desde el Mediterráneo oriental hasta el extremo occidental de la Península Ibérica, con presencia en el norte de África y en las principales islas del Mediterráneo central (Hartley, 1973b, 52-53). Su difusión hacia el norte de Europa se ha relacionado con una vía de comercialización a través del puerto de Marsella y de los ríos Ródano y Rin, alcanzando las actuales 
Alemania y Holanda y, de nuevo por vía marítima, Gran Bretaña (Hartley, 1973b, 57).

En la Península Ibérica se ha constatado una amplia distribución de morteros itálicos en yacimientos tan dispares como Augusta Emerita (Sánchez, 1990, 125, fig. 2), Conimbriga (Alarçao, 1976, 75-76, fig. XVIII, 48 a 50) y Scallabis, en Santarém, Portugal (Arruda y Viegas, 2004, 342-343, fig. 2), Lucus Augusti (Alcorta, 1995), el Chao Samartín, en Grandas de Salime, Asturias (Hevia y Montes, 2009a, 644, fig. 2.6 y 2.7; Hevia y Montes, 2009b, 37-38, fig. 13 y 16.3), Paredes de Nava (Balil, 1982, 109-111) y Herrera de Pisuerga (Pérez y Fernández, 1989, 77-78, fig. 12) en la provincia de Palencia, Libia (Herramélluri) y Calagurris Iulia en La Rioja (Luezas, 1988, 52, Luezas, 2001, 77, fig. 4), L'Alcúdia de Elche (Ramos, 1974), Tarraco, (García y Bellido, 1963, 199-200, fig. 15.1 y fig. 16), Emporiae (Almagro, 1952, 229, núm. 256 y 257; Aquilué et alii, 1984, fig. 87.16), las villas de Torre Llauder en Mataró, El Maresme (Ribas, 1972, 150-151, figs. 32 y 33) y del Camp de la Gruta en Torroella de Montgrí, Baix Empordà (Rocas y Roviras, 1995) o Colonia Patricia Corduba (García y Bellido, 1963, 200, fig. 18).

\section{CATÁlOGO}

Los morteros recogidos en este catálogo corresponden a los denominados tipos Dramont D 1 y 2, individualizados por J. P. Joncheray en el estudio de los materiales del navío naufragado frente al cabo del mismo nombre en las costas de Provenza (Joncheray, 1972, 1973 y 1974). Se trata de un material bastante fraccionado, compuesto casi exclusivamente por fragmentos de borde con parte de la pared del cuerpo en el que tan sólo un ejemplar conserva, muy parcialmente, el arranque del anillo de su base ( $\mathrm{n}^{\circ} .35$ del catálogo).

Los morteros del tipo Dramont D 1, catalogados por M. Vegas como «morteros de borde horizontal» o grupo 7c (Vegas, 1973, 32-33), se distinguen por un cuerpo de escasa altura y desarrollo troncocónico muy exvasado, rematado por anchos bordes horizontales en forma de ala. En su extremo exterior presenta un engrosamiento hacia la parte inferior del ala y en el extremo opuesto forma un baquetón sobreelevado que marca la unión del borde con el cuerpo. Apoya sobre una resistente base de tipo anular, gruesa y de perfil ancho.

El receptáculo interior de este tipo de morteros es de forma cóncava y bastante abierta. Por lo general se hallan recubiertos por una capa de abrasivo arenoso aplicado sobre la pasta fresca destinado a facilitar la molturación de los alimentos y a reforzar la pared del vaso. Desaguan por medio de vertederas sobresalientes prácticamente horizontales, dotadas de un canalillo central cuyas paredes laterales son la prolongación del baquetón del labio.

El inicio de su producción se sitúa a finales de época republicana (Vegas, 1973, 32-33, Aguarod, 1991,
137-138), perdurando a lo largo del siglo I d. C. hasta finales de la centuria, cuando son sustituidos por la variante Dramont D 2 tras un período relativamente largo de convivencia.

Los morteros Dramont D 2 se caracterizan por un mayor tamaño y robustez que sus predecesores, presentando un desarrollo troncocónico más elevado y, por consiguiente, una mayor capacidad. Estos recipientes están rematados por unas alas notablemente desarrolladas en anchura que describen perfiles más o menos colgantes. Una ranura por lo general bastante marcada señala la unión del cuerpo con el labio y define el inicio del receptáculo que, al igual que en el tipo anterior, suele estar recubierto interiormente por una capa abrasiva de naturaleza arenosa.

El pico vertedor es de forma trapezoidal, sobresaliente con respecto al labio del vaso y levemente inclinado. Su canal interno de desagüe se enmarca entre dos acanaladuras convergentes que se prolongan desde la estría del borde interno.

La evolución tipológica de este mortero fue establecida inicialmente por K. F. Hartley $(1973,55)$ atendiendo a la progresiva tendencia a la horizontalidad de sus alas y posteriormente confirmada por los materiales recuperados del pecio $\mathrm{C}$ del Grand Bassin, en Gruissan (Sabrié y Sabrié, 1981, 89-90) y por la seriación elaborada por C. Aguarod (1991, 140-141) de los morteros hallados en la Tarraconense.

En esta última clasificación, la fase 1 corresponde a las producciones iniciales datadas en época de Tiberio y los morteros presentan labios engrosados y macizos ligeramente colgantes. En los ejemplares posteriores, definida como la fase 2 , se aprecia un progresivo alargamiento de los bordes, cuyo perfil se dobla notablemente hacia la parte inferior del vaso y cronológicamente se sitúan entre finales del reinado de Tiberio y principio de época de Claudio. En la denominada fase 3 , con inicio a finales de época de Claudio y hasta época flavia, aparece la ranura interior del borde, coincidiendo con un proceso de horizontalización de las alas que culmina en la fase 4, que corresponde a las últimas producciones de época antonina (Figs. 1 y 2).

Las pastas empleadas en la fabricación de los morteros de Segobriga son muy homogéneas, lo que corresponde a su procedencia centroitálica y a la total ausencia de imitaciones producidas en talleres hispanos. Los morteros de la forma Dramont D 1 se caracterizan por arcillas muy depuradas y finas, de color rosado rojizo más o menos pálido, y algo untuosas al tacto. Presentan desgrasantes prácticamente inapreciables, con partículas brillantes de muy pequeño tamaño y superficies libres de tratamiento específico, a excepción del abrasivo interno.

Las pastas de la variante Dramont D 2 son asimismo finas aunque tal vez algo menos depuradas, de tonos por lo general más rojizos o anaranjados. Sus superficies suelen presentar engobes de coloración beige pálida o amarillenta, de tacto suave e incluso alisado. Sus desgrasantes son más apreciables que en el tipo 

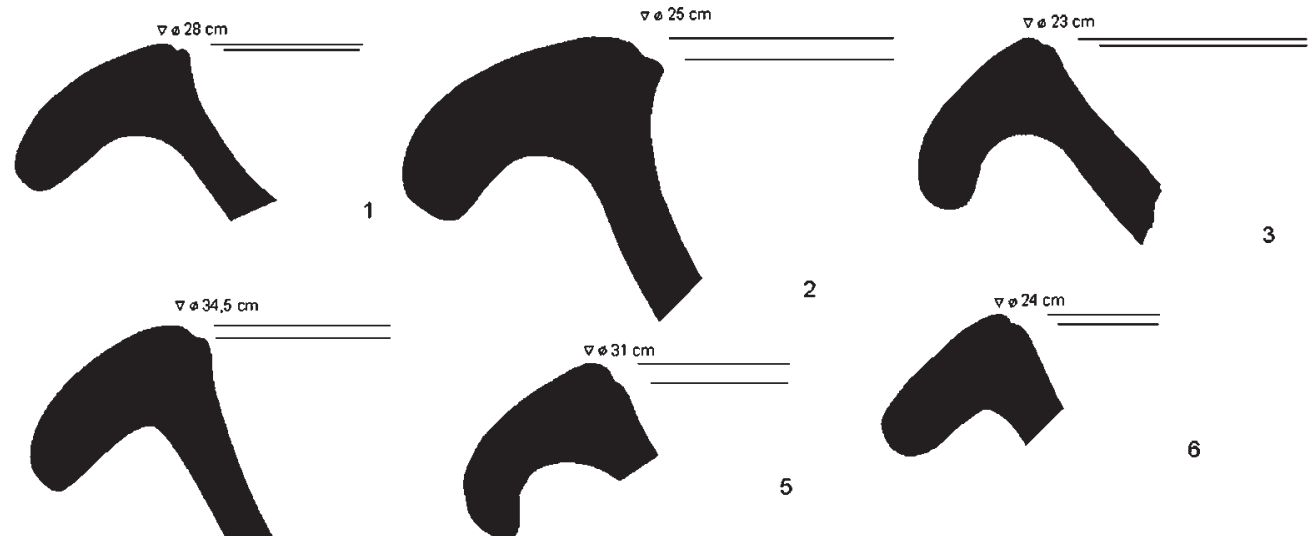

2

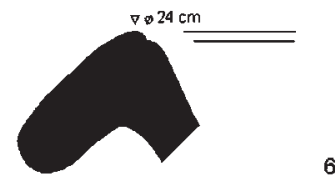

5

6
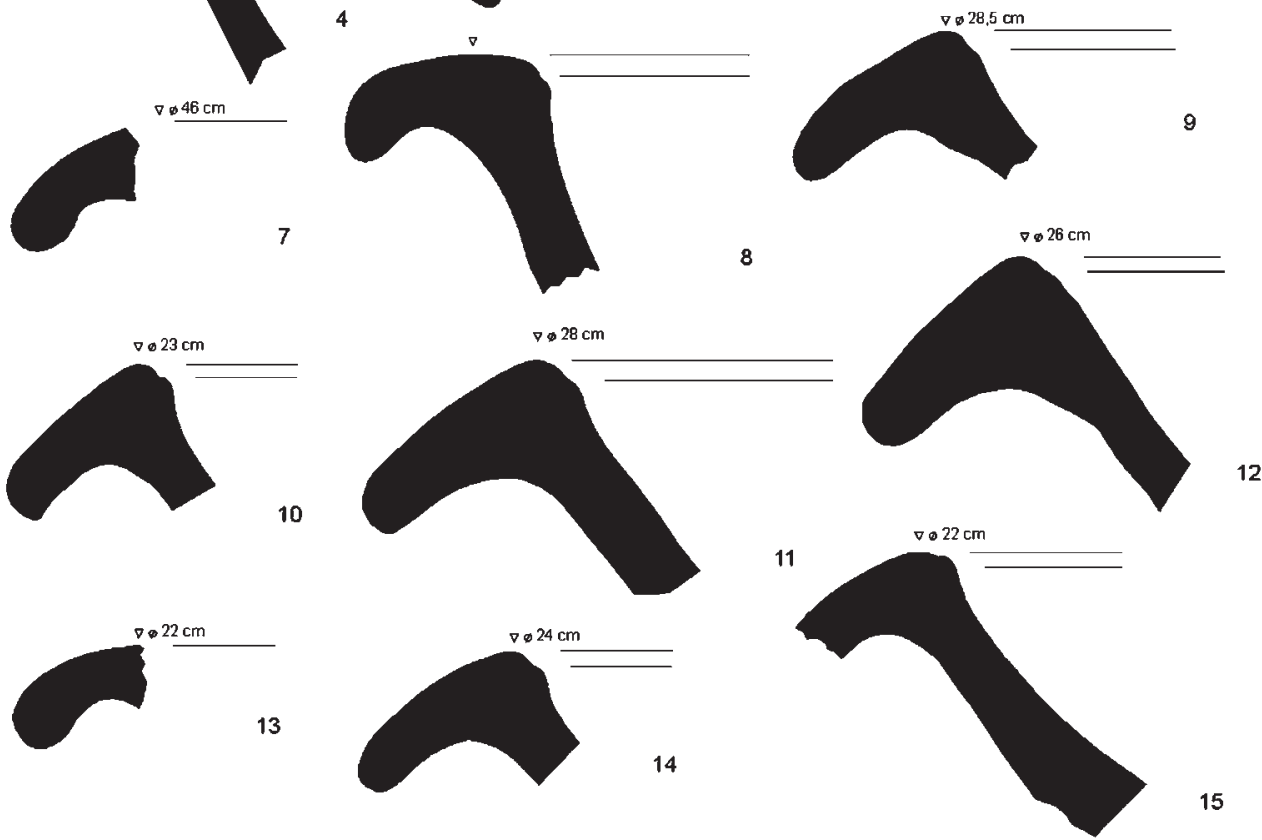

15

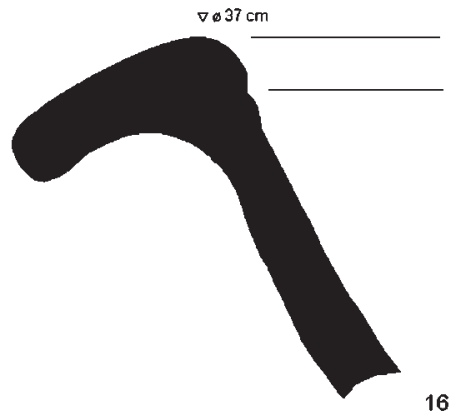

16

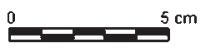

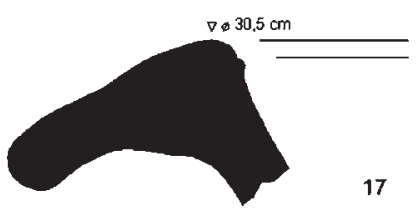

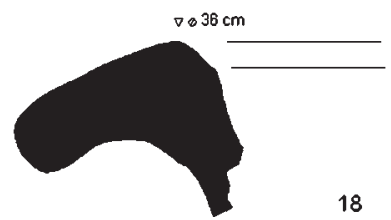

18

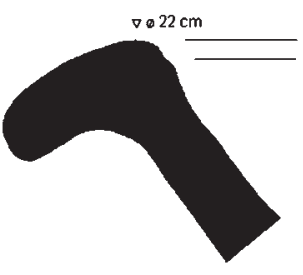

19

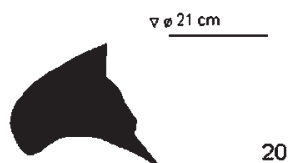

Figura 1: Morteros de producción centroitálica hallados en Segobriga. El número de la pieza corresponde al del catálogo ( $\mathrm{n}^{\circ}$. 1 al 20).

anterior, presentando en su composición finos granos de arena, minerales de procedencia volcánica, cuarzo y partículas brillantes de mica negra y dorada. También se aprecian ocasionales fragmentos de chamota y chinas de mayor tamaño, con defectos de amasado que llegan a crear pequeñas vacuolas en el núcleo de las piezas.

Los sellos sobre mortaria no son muy habituales, por lo que son escasos y, por tanto, muy poco conocidos los alfareros de estas producciones. En todo caso, la presencia de sello es más habitual en los morteros del tipo Dramont D 2. Las producciones más antiguas, anteriores al 70 d.C., pueden llevar una única estampilla contigua al pico vertedor (Luezas, 1991, 65), pero en los ejemplares posteriores se generaliza el uso de dos marcas que se disponen invariablemente en el labio a ambos lados de la vertedera. Se encuadran siempre en el interior de cartelas rectangulares, herederas de los 

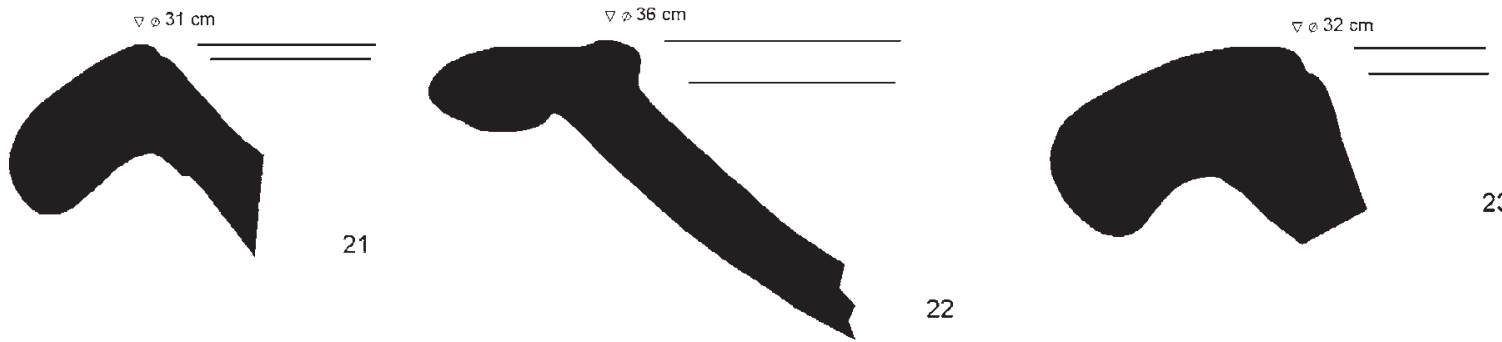

22
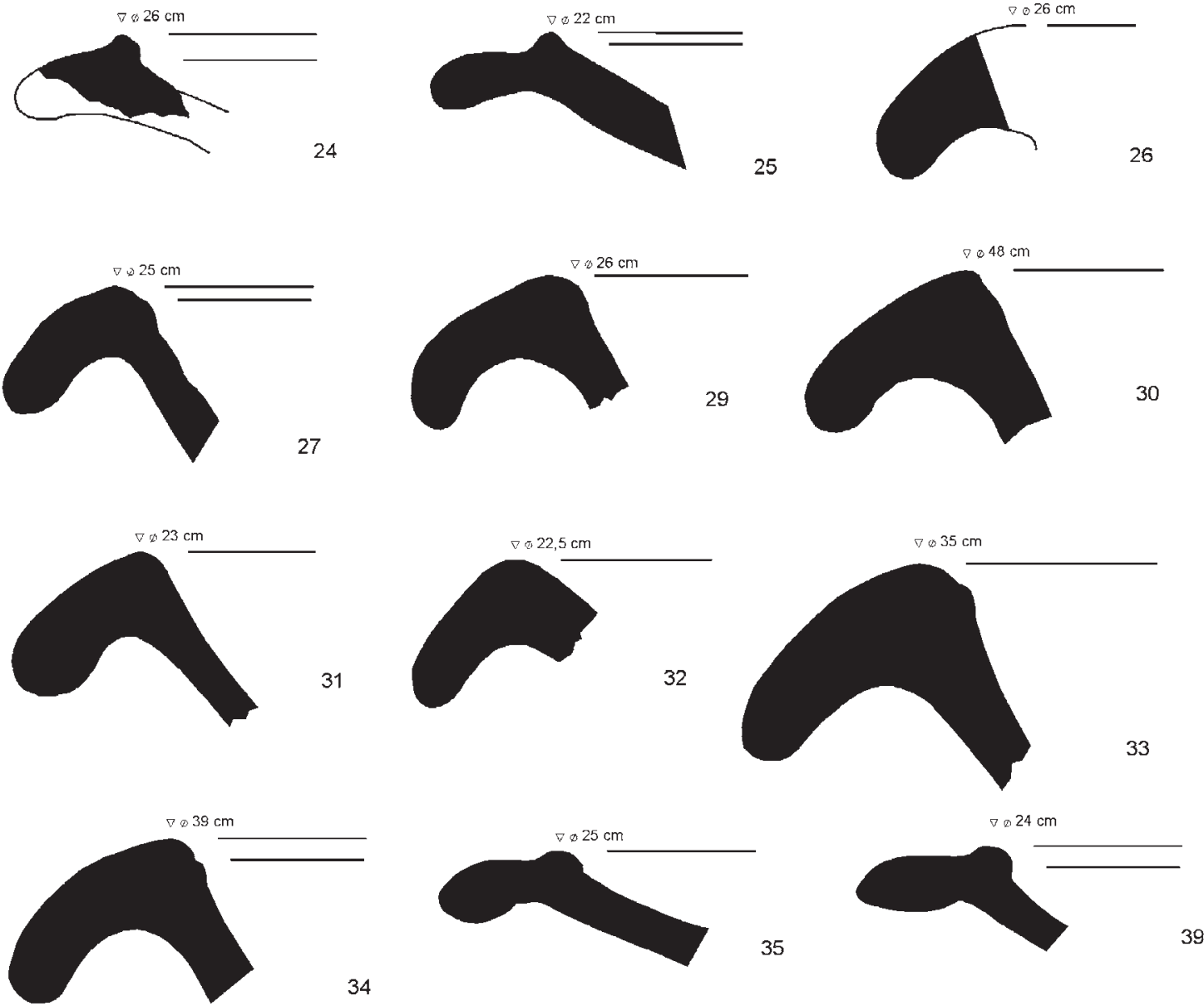

34
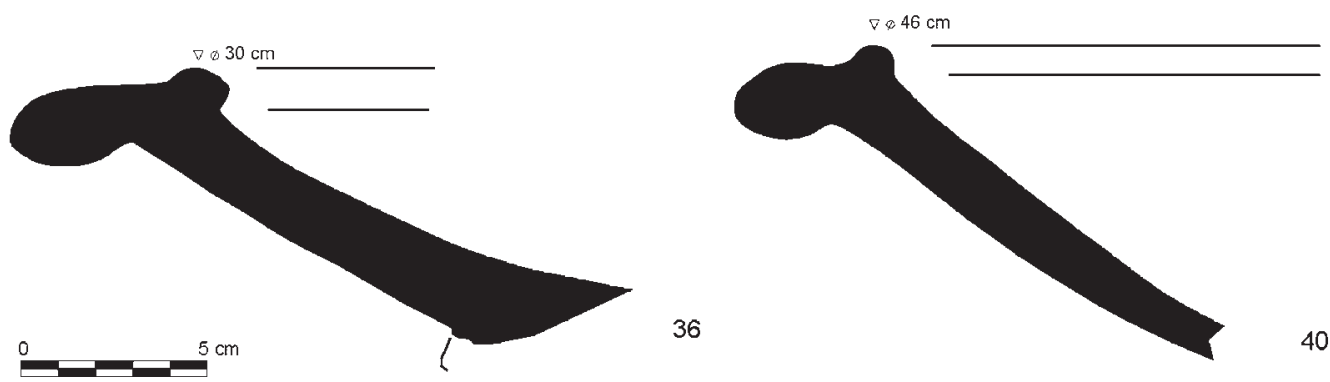

Figura 2: Morteros de producción centroitálica hallados en Segobriga. El número de la pieza corresponde al del catálogo ( ${ }^{\circ}$. 21 al 40).

sellos del material latericio, que ocupan una posición perpendicular al eje del labio. Las inscripciones suelen distribuirse en dos líneas de texto, a veces separadas por un listel o banda decorada (Aguarod, 1991, 145).

La práctica de estampillar los morteros se inicia hacia mediados del siglo I d. C. y continúa hasta la mitad del siglo II d. C. (Hartley 1973, 50).
De los cuarenta morteros recuperados en las excavaciones de Segobriga, tan sólo siete ejemplares presentan sello. Todos ellos pertenecen a la variante Dramont D 2, con características morfológicas correspondientes a la fase 3 , de producción en época flavia.

A continuación, presentamos el catálogo de morteros hallados en Segobriga: 
1. Anfiteatro. Campaña 1982. (nº de inv.: 162973). Hallado en la campaña de excavaciones del año 1982 en el anfiteatro (área 3, cuadrícula 1, nivel 2).

Forma Dramont D 2, fase 3. Borde de mortero con gran ala ganchuda y estría marcada en la parte superior del vaso. Pared interior recubierta de abundante abrasivo arenoso de grano grueso con partículas blancas, negras y rojizas. Pasta fina y suave al tacto de color beige con chamota y desgrasante brillante. Diámetro máx.: $37 \mathrm{~cm}$; diámetro boca: $28 \mathrm{~cm}$.

Presenta sello completo en cartela, de 3,5 x $6,5 \mathrm{~cm}$ (Sánchez, 1990, 123, 125-126: no 3, fig 3; Aguarod, 1991, 147, fig. X. h). El sello se sitúa en el borde del mortero con lectura desde el exterior al interior del recipiente y con orientación transversal al borde. Hoja de palma en la segunda línea entre la $r$ y fecit. La primera letra sólo conserva el trazo horizontal final de una M. La altura de las letras es de 1,2 cm. El sello corresponde al punzón 27.23 de la clasificación de Pallecchi $(2002,209)$.

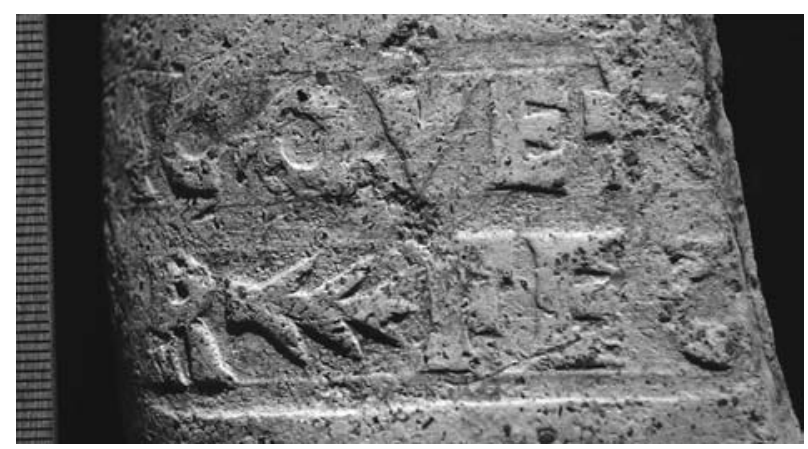

Su texto dice:

\section{[St(ati] M(arcius) C(eler) QV(i)ETIO(onis) [-]R FEC(it)}

Cronología: fin de época de Claudio-época flavia / inicios época antonina.

2. Puerta Norte. Campaña 1987. Sector 9, cuadrícula 1987/1. $\mathrm{N}^{\mathrm{o}}$. de registro arqueológico: $87 / \mathrm{Y} / \mathrm{IV}, \mathrm{n}^{\circ}$ 530 (con sellos $n^{\circ}$. de inv.: 195047) y $531\left(n^{\circ}\right.$. de inv.: 195048). Se halló en un nivel fechado en época flavia (Almagro-Gorbea y Lorrio, 1989, 153).

Forma Dramont D 2, fase 3. Cuatro fragmentos de borde y piquera de un mismo mortero con ala colgante, algo ganchuda y arranque de las paredes del cuerpo de forma hemiesférica. Pico vertedor trapezoidal con su extremo redondeado, de desarrollo prácticamente vertical, algo inclinado hacia abajo. Su conducto está formado por sendos rebordes convergentes hacia el exterior que enlazan con la marcada ranura que remata el borde interno de la pieza. La cara interna del mortero está recubierta por una capa de abundante abrasivo arenoso. Pasta fina, algo granulosa, de color rosado oscuro con partículas rojizas, negras y doradas brillantes. Superficie lisa de tacto untuoso. Diámetro máx.: $38 \mathrm{~cm}$; diámetro boca: $25 \mathrm{~cm}$.
Conserva las dos estampillas completas a ambos lados de la vertedera, en el que se repite el mismo texto. El sello de la derecha es convergente respecto a la vertedera y su lectura se realiza desde el interior al exterior del borde, mientras el sello de la izquierda es divergente respecto a la vertedera y su lectura se realiza igual al anterior. El texto se dispone en dos líneas en el interior de una cartela, de 3,5 x $6,5 \mathrm{~cm}$. La altura de las letras es de 1,2 cm. Interpunción triangular con el vértice hacia abajo en la $1^{\mathrm{a}}$ línea. Nexo de TI. El sello corresponde al punzón 18.35 de la clasificación de Pallecchi (2002, 139).

Su texto dice:

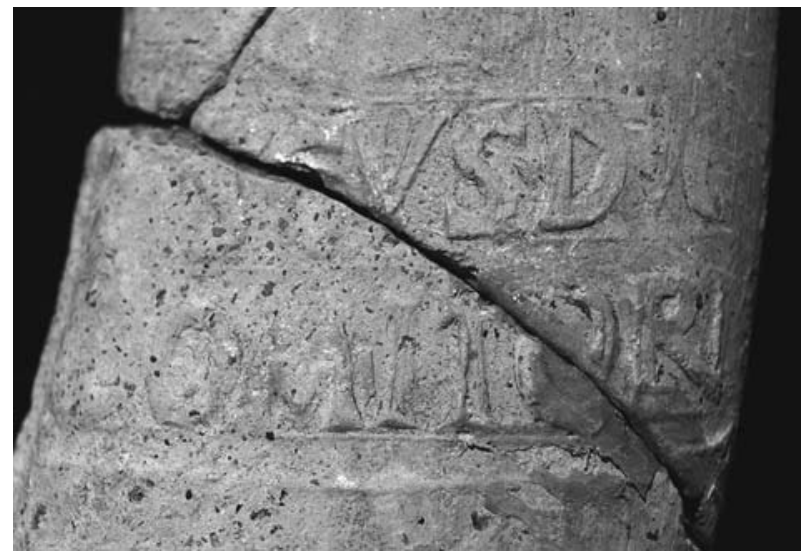

$$
\begin{aligned}
& {[\text { Pri]scus } \cdot \text { DVO(rum) }} \\
& \text { DOMITIOR(um) }
\end{aligned}
$$

derecha

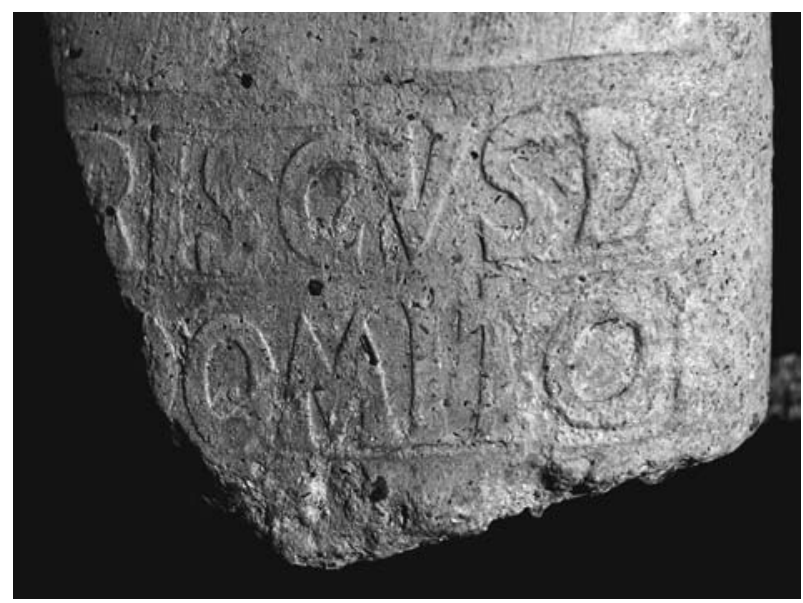

$[P] R I S C V S \cdot D[V][o](r u m)$

izquierda DOMITIOR(um)

3. Torre octogonal junto a la muralla oriental. Campaña 1999. UE 74, no. 131 y 132 (nº de inv.: 030522 y 030523). Se halló en un nivel de tierra grisácea cubierto por el nivel vegetal en el interior del torreón octogonal. Todos los ejemplos de cerámica repertoriados en esta unidad son claramente de cronología altoimperial. Dentro de la cerámica fina destaca la presencia de fragmentos decorados de terra sigillata gálica, terra sigillata hispánica, formas Drag. 27 y Drag. 37, un informe de hispánica brillante y cerámica pintada. 
También se han documentado importaciones itálicas de cerámica de cocina con una datación del siglo I d.C.

Forma Dramont D 2, fase 3. El primer fragmento conserva el borde de mortero con ala muy colgante e inicio de la pared de desarrollo hemisférico. Superficie interna del vaso con abrasivo arenoso compuesto por granos rojizos y dorados brillantes. Pasta muy fina de tacto untuoso y color rosado amarillento muy pálido, casi blanquecino. Desgrasante arenoso no muy abundante con partículas de mica dorada. Diámetro máx.: $30 \mathrm{~cm}$; diámetro boca: $23 \mathrm{~cm}$.

Conserva sello completo en cartela, de $3 \times 6 \mathrm{~cm}$, localizado a la izquierda del pico vertedor sobre el labio y dispuesto transversalmente a él, con lectura hacia el interior del mortero. El texto se distribuye en dos líneas, con letras de $1 \mathrm{~cm}$ de altura. Nexo de AL y TA. El sello corresponde al punzón 18.50 ó 18.51 de la clasificación de Pallecchi (2002, 145-147).

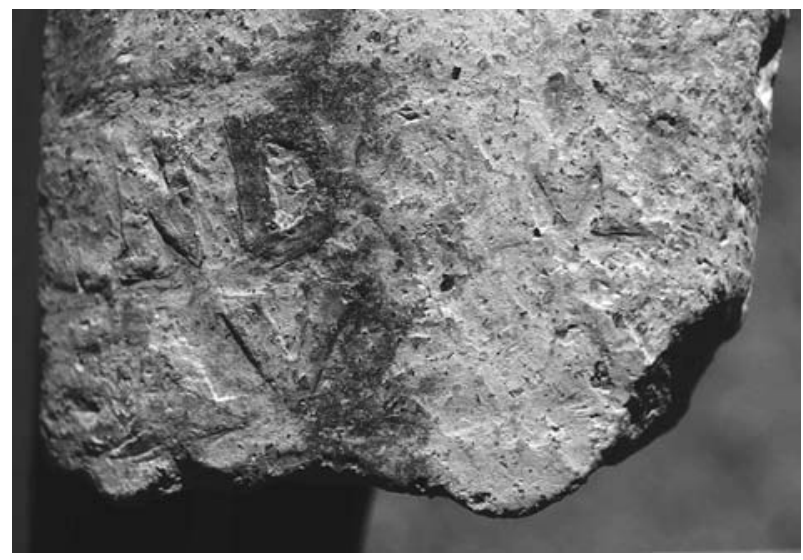

Su texto dice:

\section{CN(aei) DOM(iti) \\ SALVTAR(is)}

El segundo fragmento conserva pico y borde de mortero. Pico prácticamente horizontal de forma troncocónica y remate semicircular con laterales rectilíneos sobrealzados. Borde con arranque del ala, que no se conserva y estría interior en el inicio del receptáculo. Paredes interiores recubiertas de abundante abrasivo arenoso con granos rojizos y blancos, algunos brillantes. Pasta muy clara, de color rosado amarillento, muy fina y untuosa. Desgrasante arenoso con abundante chamota. Diámetro máx.: 33,2 cm; diámetro boca: $23 \mathrm{~cm}$.

Aunque los dos fragmentos no llegan a pegar, son de la misma pieza.

Cronología: fin de época de Claudio-época flavia / inicios época antonina.

4. Casa del procurador minero, Caio Iulio Silvano. Estancia 3. Campaña 1999. UE 1811, nº 179 (nº. de inv.: 033803). Se halló en un nivel de tierra de color marrón grisácea, muy suelta, con restos de carbón. Los materiales cerámicos recuperados en este nivel son terra sigillata gálica, formas Drag. 15/17, 18, 24/25, 27, 29, 30, Ritt. 8, lucernas, entre ellas, una Deneuve IX a, con disco decorado con imagen de una Medusa, paredes finas, cuencos de rojo pompeyano, cerámica pintada, formas Abascal 16 y 17, cerámica de cocina y común alto-imperial y entre el material anfórico, se encuentran tres pivotes de ánfora itálica, que proporcionan una cronología de finales de época julio-claudia e inicios de época flavia.

Forma Dramont D 2, fase 3. Fragmento de borde de mortero con gran ala colgante y arranque de la pared del vaso. Estría marcada en el borde interior. Superficie interna con abrasivo arenoso de color rosado claro con partículas negruzcas, blancas y rojizas. Pasta de color beige, depurada. Desgrasante arenoso brillante y chamota. Diámetro máx.: $43 \mathrm{~cm}$; diámetro boca: $34,5 \mathrm{~cm}$.

Cronología: fin de época de Claudio-época flavia / inicios época antonina.

5. Aula basilical. Campaña 2000. UE 3161, no. 8 (nº. de inv.: 053842). Se halló en un nivel conformado por piedras de mediano tamaño y tejas en la nave central del edificio. Entre los materiales cerámicos recuperados en este relleno se encuentran formas de terra sigillata hispánica (Drag. 36 y 37), un asa de ánfora Dressel 2/4, cerámica común de contenedor y ollas de cerámica de cocina altoimperial. La cronología del estrato se sitúa hacia finales del siglo I y principios del II d. C.

Forma Dramont D 2, fase 3. Fragmento de borde de mortero con gran ala colgante y arranque de la pared del vaso. Presenta una estría muy marcada señalando el inicio del vaso en el borde superior. En la cara interna se aprecian restos muy desgastados de abrasivo arenoso. Arcilla fina y suave de color grisáceo con partículas abundantes de mica dorada. La pieza está quemada. Diámetro máx.: $39 \mathrm{~cm}$; diámetro boca: 31 $\mathrm{cm}$.

Presenta sello en el interior de cartela, de [2,1] x $6,5 \mathrm{~cm}$. Se sitúa en el borde del mortero con lectura desde el exterior al interior del recipiente y en posición diagonal al borde. Conserva la parte inferior de una $\mathrm{M}$ inicial y parte de un trazo vertical a continuación en la $1^{\mathrm{a}}$ línea y la $2^{\mathrm{a}}$ línea está completa. La altura de las letras es de 1,3 cm. Nexo de ND. El sello corresponde al punzón 28.4 de la clasificación de Pallecchi (2002, 223-224).

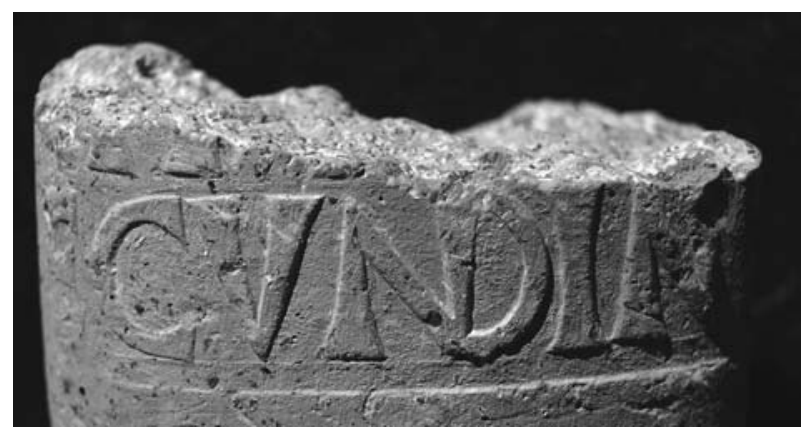


El texto dice:

\section{M(arcus) M[arius] \\ [S]ECVNDIN(us)}

Cronología: fin de época de Claudio-época flavia / inicios época antonina.

6. Plaza del foro. Campaña 2001. UE 5125, no .236 $\left(n^{\circ}\right.$. de inv.: 067624). Se recuperó en un relleno de tierra de color grisáceo, arcillosa, suelta, con abundantes piedras de pequeño tamaño, fechado en época califal por la presencia de cerámica vidriada, ollas de cocina y común a mano. La cerámica de carácter residual está ampliamente representada con formas cerámicas de época bajo-imperial (hispánica tardía y terra sigillata africana clara C) y alto-imperial (terra sigillata gálica e hispánica, ánfora Dressel 2/4 de la Tarraconense y un cuenco de rojo pompeyano, forma Luni 5).

Forma Dramont D 2, fase 3. Fragmento de borde de mortero con ala colgante. Estría marcada en el borde interior. La pared interna presenta restos de abrasivo arenoso rojizo. Arcilla fina y depurada rosada de superficie lisa con desgrasante arenoso. Diámetro máx.: $31,4 \mathrm{~cm}$; diámetro boca: $24 \mathrm{~cm}$.

Conserva sello en labio, dispuesto en diagonal al borde y con lectura desde el interior al exterior de la pieza. El texto está distribuido en dos líneas, separadas por una banda decorada con hojas de hiedra. Presenta cartela, de $2,2 \mathrm{~cm}$ y $5 \mathrm{~cm}$, que engloba a la primera línea y la decoración. La altura de las letras en la línea 1 es de 1,3 cm y en la línea 2 miden $1,1 \mathrm{~cm}$. El sello corresponde al punzón 11.9 de la clasificación de Pallecchi $(2002,105)$.

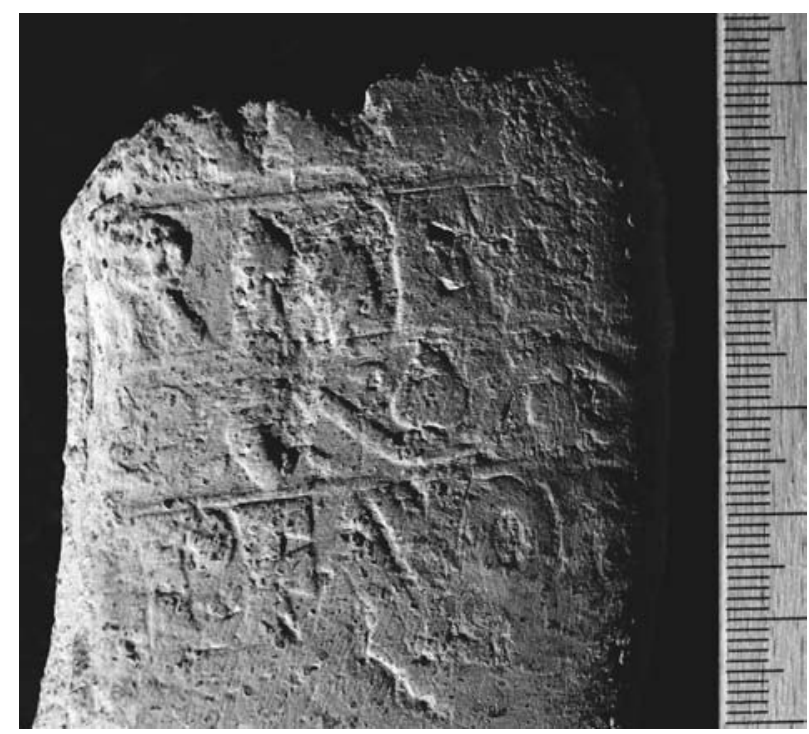

El texto dice:

[He]RMET(is)

[C(aii) Cal]P(etani) $\cdot \mathrm{FAVO}($ ris $)$
Cronología: fin de época de Claudio-época flavia / inicios época antonina.

7. Plaza del foro. Campaña 2001. UE 5223, n. ${ }^{\circ} 7\left(n^{\circ}\right.$. de inv.: 072716). Nivel de tierra de color rojizo, semicompacta, arcillosa, con abundantes piedras y material constructivo, con presencia de terra sigillata hispánica y un borde de ánfora vinaria de la Tarraconense, forma Oberaden 74. La cronología del estrato se sitúa entre finales del siglo I y principios del II d. C.

Forma Dramont D 2, fase 4. Fragmento de ala de mortero de perfil colgante. Arcilla de color beige rosado de superficie áspera. Desgrasante compuesto por partículas brillantes y chamota no muy abundantes. Diámetro máx.: $55 \mathrm{~cm}$; diámetro boca: $46 \mathrm{~cm}$.

Cronología: Época antonina.

8. Plaza del foro. Campaña 2001. UE 5245, $n^{\circ} .71\left(n^{\circ}\right.$. de inv.: 073086). Relleno de tierra de color grisáceo, suelta, arcillosa, con abundantes piedras de pequeño y mediano tamaño, fechado en época visigoda.

Forma Dramont D 2, fase 4. Fragmento de borde y cuerpo de un mortero con gran ala algo colgante. Presenta restos de abrasivo arenoso en la pared interior. Arcilla muy fina y untuosa al tacto de color amarillento. Desgrasante arenoso con partículas brillantes. Diámetro de la boca indeterminado.

9. Pórtico meridional del foro. Campaña 2002. UE 5583, $\mathrm{n}^{\circ} .41\left(\mathrm{n}^{\circ}\right.$. de inv.: 077162). Relleno de tierra de color gris, suelta, con piedras de mediano tamaño, fechado en época emiral.

Forma Dramont D 2, fase 3. Fragmento de borde de mortero con gran ala colgante. Presenta indicios de una estría en el borde superior y conserva restos de abrasivo arenoso en la cara interna con partículas rojizas y blancas. Arcilla fina y depurada de color rosado de tacto untuoso con engobe beige amarillento al exterior. Abundantes partículas negras y de mica dorada. Diámetro máx.: $38 \mathrm{~cm}$; diámetro boca: $28,5 \mathrm{~cm}$.

Cronología: fin de época de Claudio-época flavia / inicios época antonina.

10. Pórtico meridional del foro. Campaña 2002. UE 5679, $\mathrm{n}^{\mathrm{o}} 41$ ( $\mathrm{n}^{\mathrm{o}}$. de inv.: 080438). Nivel de derrumbe de la basílica forense localizado en el extremo este del pórtico meridional. Entre los materiales recuperados en este nivel se hallaron formas de terra sigillata clara $\mathrm{C}$, entre las que destaca un plato Hayes 49 y terra sigillata Hispánica tardía, forma Ritt. 8. La ausencia de clara D y de formas más tardías en las producciones de sigillata consienten una cronología en el siglo IV d. C.

Forma Dramont D 2, fase 3. Fragmento de borde de mortero con gran ala exvasada y estría en el borde interno marcando el comienzo del vaso. Arranque de la pared con la superficie interior recubierta de abrasivo de tipo arenoso con granos rojizos, blancos y negros brillantes. Arcilla de color anaranjado de superficie áspera con abundante desgrasante brillante, mica 
negra y dorada, y chamota. Diámetro máx.: $31,2 \mathrm{~cm}$; diámetro boca: $23 \mathrm{~cm}$.

Cronología: fin de época de Claudio-época flavia / inicios época antonina.

11. Pórtico meridional del foro. Campaña 2002. UE 5759, $n^{\circ} .58$ ( $n^{\circ}$. de inv.: 082847). Nivel de derrumbe de tierra de color marrón anaranjado, muy compacto, con algún fragmento de teja, fechado en la segunda mitad del siglo IV d. C.

Forma Dramont D 2, fase 3. Fragmento de borde de mortero con gran ala colgante y estría bastante marcada en el extremo superior de la pieza. Pared gruesa de desarrollo hemisférico. En la cara interna se aprecian restos de abrasivo arenoso muy desgastado. Arcilla muy fina y untuosa de color rosado con partículas de mica dorada y algo de chamota.

Diámetro máx.: $39 \mathrm{~cm}$; diámetro boca: $28 \mathrm{~cm}$.

Cronología: fin de época de Claudio-época flavia / inicios época antonina.

12. Pórtico meridional del foro. Campaña 2003. UE $7000, n^{\circ} .432$ ( $n^{0}$. de inv.: 094348). Nivel superficial.

Forma Dramont D 2, fase 3. Fragmento de borde de mortero con ala colgante de gran tamaño y estría en el borde interno que marca el inicio del vaso. Restos internos de abrasivo arenoso bastante erosionado con partículas negruzcas, blancas y rojizas. Arcilla depurada de color rosado claro, de tacto áspero y algo untuoso. Desgrasante compuesto por abundantes partículas rojizas y doradas brillantes. Diámetro máx.: $36 \mathrm{~cm}$; diámetro boca: $26 \mathrm{~cm}$.

Cronología: fin de época de Claudio-época flavia / inicios época antonina.

13. Pórtico meridional del foro. Campaña 2003. UE $7001, n^{\circ} .88\left(n^{\circ}\right.$. de inv.: 096086). Nivel de relleno de época moderna.

Forma Dramont D 2, fase 4. Fragmento de ala de mortero de perfil ganchudo no muy desarrollado. Pasta muy fina y depurada de color anaranjada y superficie beige de tacto untuoso. Desgrasante compuesto por partículas muy finas de mica dorada y escasa chamota fina. Diámetro máx.: $23 \mathrm{~cm}$; diámetro boca: 22 $\mathrm{cm}$.

Cronología: época antonina.

14. Pórtico meridional del foro. Campaña 2003. UE 7004, $n^{\circ} .46$ ( ${ }^{\circ}$. de inv.: 096394). Nivel de tierra de color gris ceniciento de textura arenosa, muy suelta, con piedras de pequeño tamaño, fechado en el siglo IX.

Forma Dramont D 2, fase 3. Fragmento de borde de mortero con ala fina colgante y estría interior marcando el inicio del recipiente. Pared interna con restos de abrasivo arenoso rojizo y blanquecino. Arcilla muy fina de color beige de superficie lisa. Desgrasante arenoso con chamota. Diámetro máx.: $33,6 \mathrm{~cm}$; diámetro boca: $24 \mathrm{~cm}$.
Cronología: fin de época de Claudio-época flavia / inicios época antonina.

15. Pórtico meridional del foro. Campaña 2003. UE $7377, n^{\circ} .36$ ( $n^{\circ}$. de inv.: 106493). Nivel de derrumbe de la curia caído sobre el pórtico meridional. Su datación se sitúa entre el segundo cuarto del siglo IV y las primeras décadas del siglo $\mathrm{V}$, por la presencia de un fragmento de un borde de plato de terra sigillata clara D, forma Hayes 59.

Forma Dramont D 2, fase 3. Fragmento de borde de mortero con ala exvasada colgante a la que le falta el borde. Presenta una estría no muy marcada en la parte superior y restos mal conservados de abrasivo interno con partículas brillantes y negruzcas. Pasta de color beige grisáceo fina y untuosa con partículas de mica dorada como desgrasante. Diámetro boca: $22 \mathrm{~cm}$.

Cronología: fin de época de Claudio-época flavia / inicios época antonina.

16. Pórtico meridional del foro. Campaña 2003. UE $7380, n^{\circ} .16$ (nº de inv.: 106679). Relleno de tierra de color amarillenta muy compacta, fechado en el siglo V d. C.

Forma Dramont D 2, fase 4. Fragmento de borde y pared de mortero con gran ala colgante y estría marcada en la parte interior del borde. Cuerpo de desarrollo hemisférico con pared interna recubierta de abrasivo arenoso muy desgastado con partículas negras, rojizas y doradas. Arcilla muy fina, de tacto untuoso, con núcleo rosado y superficie beige muy pálida, casi amarillenta. Desgrasante brillante con chamota. Diámetro máx.: 48,8 cm; diámetro boca: $37 \mathrm{~cm}$.

Cronología: época antonina.

17. Pórtico meridional del foro. Campaña 2003. UE 7384, $\mathrm{n}^{\mathrm{o}}$. 68 ( $\mathrm{n}^{\mathrm{o}}$. de inv.: 107010). Se corresponde con un nivel de cenizas, suelta y arenosa, con carbones, que se fecha por el material cerámico en época tardo-romana.

Forma Dramont D 2, fase 3-4. Fragmento de borde de mortero con ala colgante muy desarrollada. Presenta una marcada estría en la parte interior del borde que señala el inicio de la pared. Su cara interna conserva abundantes restos de abrasivo arenoso bastante desgastado, con partículas negras, rojizas, blancas y doradas. Arcilla fina de color rosado pálido con superficie beige blanquecina. Tacto untuoso. Desgrasante brillante con chamota. Diámetro máx.: 44,4 cm; diámetro boca: $30,5 \mathrm{~cm}$.

Cronología: época antonina.

18. Pórtico meridional del foro. Campaña 2003. UE 7384, $\mathrm{n}^{\circ} .132\left(\mathrm{n}^{\circ}\right.$. de inv.: 107073). Las circunstancias del hallazgo son las mismas que la pieza $\mathrm{n}^{\mathrm{o}} 15$.

Forma Dramont D 2, fase 4. Borde de mortero con ala muy desarrollada colgante. Estría marcada en el borde interior. Conserva restos escasos y muy desgastados de abrasivo en la cara interna, con partículas 
rojizas y blancas. Arcilla fina de color rosado de tacto suave algo untuoso. Abundante desgrasante con partículas brillantes y chamota. Diámetro máx.: $46 \mathrm{~cm}$; diámetro boca: $36 \mathrm{~cm}$.

Cronología: época antonina.

19. Pórtico meridional del foro. Campaña 2003. UE 7386, nº 90 ( $n^{\circ}$. de inv.: 107371). Relleno de tierra de color marrón anaranjado con carboncillos y escasos fragmentos de teja, fechado en época tardo-romana.

Forma Dramont D 2, fase 4. Borde de mortero con gran ala de labio ganchudo. Muestra una estría marcada en el borde interior, señalando el inicio del recipiente. Cuerpo hemisférico de gruesas paredes. Presenta abundante abrasivo arenoso en la cara interna compuesto por granos rojizos y negros brillantes. Arcilla de color rosado claro con abundante desgrasante micáceo (mica dorada), calizo y con chinas de hasta $4 \mathrm{~mm}$ de grosor. Algunas vacuolas. Superficie lisa y fina. Diámetro máx.: $30,4 \mathrm{~cm}$; diámetro boca: $22 \mathrm{~cm}$.

Cronología: época antonina.

20. Pórtico meridional del foro. Campaña 2003. UE $7559, n^{\circ} .47$ ( $n^{\circ}$. de inv.: 114635). Relleno de tierra de color negro arcillosa y suelta, con fragmentos de tejas, fechado en época tardo-romana.

Forma Dramont D 2, fase 1. Fragmento de ala colgante de mortero. Arcilla de color rosado con chamota, cal y mica dorada como desgrasante. Superficie de color pálido untuosa al tacto. Diámetro máx.: $30 \mathrm{~cm}$.

Cronología: época de Tiberio.

21. Basílica del foro. Campaña 2003. UE 7134, nº 43 $\left(\mathrm{n}^{\circ}\right.$. de inv.: 102175). Nivel de tierra gris con carbones fechado en época bajomedieval.

Forma Dramont D 2, fase 3. Fragmento de borde de mortero con ala colgante y estría en el borde interior. Pared interna recubierta de abrasivo de tipo arenoso con granos blancos, negruzcos, rojos y dorados. Pasta áspera de color rosado con engobe beige claro. Abundante desgrasante brillante con chamota. Diámetro máx.: $38 \mathrm{~cm}$; diámetro boca: $31 \mathrm{~cm}$.

Conserva la línea de la cartela del sello de la parte superior, de 5,5 cm de longitud pero ninguna letra.

Cronología: fin de época de Claudio-época flavia / inicios época antonina.

22. Basílica del foro. Aedes sur. Campaña 2005. UE $7813, n^{\circ} 235$ ( $n^{\circ}$. de inv.: 133846). Nivel de tierra gris claro suelta y arenosa con piedras de medio tamaño, fechado en época islámica.

Forma Dramont D 1. Fragmento de borde y cuerpo de mortero con ala engrosada y reborde vertical en la parte superior. Pared gruesa de desarrollo hemisférico con abundante abrasivo arenoso, compuesto por partículas blancas, rojizas y negras en la cara interna. Pasta muy fina y depurada de color rosado con la superficie beige claro, untuosa al tacto. Desgrasante brillante prácticamente inapreciable. Diámetro máx.: 45,6 cm; diámetro boca: $36 \mathrm{~cm}$.

Cronología: finales del siglo I a. C. / siglo I d. C.

23. Vivienda tardo-romana al oeste del aula basilical. Campaña 2002. UE 8000, nº 847 (nº de inv.: 087804). La pieza se halló en un nivel superficial.

Forma Dramont D 2, fase 4. Fragmento de borde y parte del pico de un mortero con gran ala algo colgante. Conserva la mitad de un pico de gran tamaño prácticamente horizontal con reborde rectilíneo y remate circular. Presenta restos de abrasivo arenoso en la pared interior. Arcilla muy fina y untuosa al tacto de color beige pálido, casi amarillento. Desgrasante arenoso muy abundante, con partículas brillantes y algo de chamota. Diámetro máx.: 45,3 cm; diámetro boca: $32 \mathrm{~cm}$.

Presenta sello, del que se conserva la primera línea. Se sitúa en el lado derecho del pico vertedor sobre el borde, dispuesto transversalmente y con lectura del exterior al interior de la pieza. La cartela tiene unas dimensiones de $[1,6]$ x 6,1 cm. La altura de las letras es de $1 \mathrm{~cm}$. El texto dice:

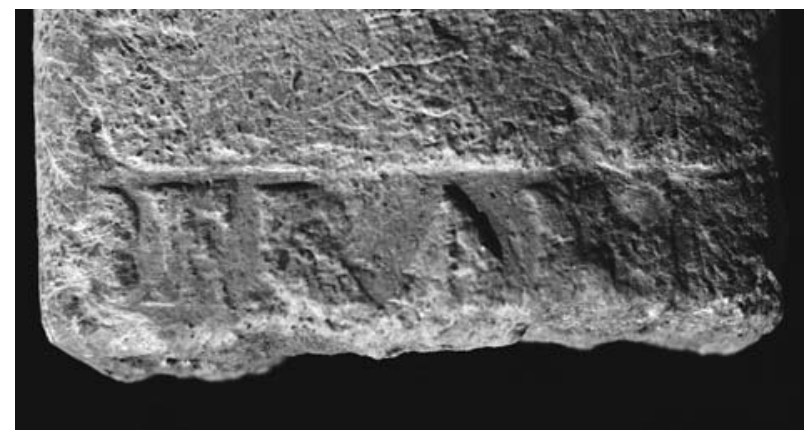

Q(uintus) ERANI(ius)

[-]

Cronología: época antonina.

24. Vivienda del siglo III junto a la puerta oriental. Campaña 2005. UE 2917, $\mathrm{n}^{\circ} .1$ ( $\mathrm{n}^{\mathrm{o}}$. de inv.: 132724). Relleno de tierra gris muy compacta y granulosa con restos de ceniza, en el que sólo se recuperó esta pieza.

Forma Dramont D 1. Fragmento de borde de mortero. Sólo conserva parte del reborde superior que marca el inicio del recipiente, un trozo de pared y el arranque del ala, fragmentada en su mitad inferior. La cara interna conserva abundantes granos de arena de color rojo y negro brillante usados como abrasivo. Arcilla fina de color rosado con la superficie beige pálida. Desgrasante compuesto por abundantes partículas doradas y escasas negras brillantes de mica. Diámetro boca: $26 \mathrm{~cm}$.

Cronología: finales del siglo I a. C. / siglo I d. C.

25. Vivienda del siglo III junto a la puerta oriental. Campaña 2005. UE 2919, $\mathrm{n}^{\circ} .10$ (n ${ }^{\circ}$. de inv.: 132752). Relleno de una fosa localizada en la estancia 3 de esta 
vivienda, fechado en la segunda mitad del siglo VIIIIX d.C.

Forma Dramont D 1. Borde de mortero de ala vertical algo ganchuda y reborde sobreelevado, marcando el inicio del recipiente. La pared interna presenta abundante abrasivo arenoso muy fino con granos rojizos, negros brillantes y dorados brillantes. Arcilla muy fina y compacta de color beige amarillento, con superficie lisa y suave. Desgrasante inapreciable. Diámetro máx.: $29,8 \mathrm{~cm}$; diámetro boca: $22 \mathrm{~cm}$.

Cronología: finales del siglo I a. C. / siglo I d. C.

26. Área del circo. Campaña 2005. UE 9211, $n^{\circ} .23$ $\left(\mathrm{n}^{\mathrm{o}}\right.$. de inv.: 135586). Relleno de tierra arcillosa de color marrón oscuro con abundantes piedras sueltas, fragmentos de tejas curvas y raíces, que se localizó en una de las catas realizadas en busca del circo en sentido norte-sur en la terraza situada al norte del anfiteatro (cata 2). El nivel se fecha en el siglo $\mathrm{V}$ por la presencia de un borde de un ánfora africana, forma Keay XXVIIb. Entre los materiales cerámicos recuperados se encuentra un importante conjunto de ánforas, tanto de la Bética (Beltrán IIa-IIb) como de la Tarraconense (Dressel 2-4). El resto de cerámica es claramente alto-imperial, con terra sigillata hispánica, hispánica brillante, cerámica común y cocina.

Forma Dramont D 2, fase 3. Fragmento de ala de mortero no muy desarrollada de perfil colgante. Arcilla depurada de color marrón claro con la superficie algo más oscura, suave y de tacto untuoso. Diámetro máx.: $35 \mathrm{~cm}$.

Cronología: fin de época de Claudio-época flavia / inicios época antonina.

27. Circo. Campaña 2005. UE $9220, n^{\circ} .87$ (no . de inv.: 135907). Nivel superficial excavado en el extremo suroeste del circo.

Forma Dramont D 2, fase 3. Fragmento de borde de mortero con ala colgante no muy gruesa y parte de la pared de desarrollo hemisférico. En el borde superior se aprecia una estría no muy marcada y en la cara interna se conservan restos de abrasivo arenoso compuesto por granos rojizos y oscuros. Pasta áspera no excesivamente depurada de color rosado oscuro. Abundante presencia de mica dorada y partículas negras. Diámetro máx.: 32,4 cm; diámetro boca: $25 \mathrm{~cm}$.

Cronología: fin de época de Claudio-época flavia / inicios época antonina.

28. Circo. Campaña 2005. UE $9226, n^{\circ} .96$ (no. de inv.: 136609). Nivel superficial en el interior de la arena del circo, junto a la tribuna del graderío sur (cata 9).

Forma Dramont D 2, fase 3-4. Fragmento de pico de mortero de gran grosor. Conserva sólo su mitad longitudinal. Arcilla muy rugosa de color rosado rojizo con superficie amarillenta. Abundante desgrasante con mica dorada y chamota. Diámetro boca: $22 \mathrm{~cm}$.

Cronología: época antonina.
29. Circo. Campaña 2005. UE 9297, $n^{\circ} .109\left(n^{\circ}\right.$. de inv.: 137389). Las circunstancias del hallazgo son las mismas que la pieza $\mathrm{n}^{\circ} 27$.

Forma Dramont D 2, fase 3. Borde de mortero con gran ala ganchuda. Presenta una estría marcando en el borde interior el inicio del recipiente, que presenta en su pared interna un abrasivo muy fino de naturaleza arenosa compuesto por granos rojizos, negruzcos y dorados. Pasta de color rosado pálido muy fina, untuosa, con desgrasante arenoso muy fino y mica dorada. Diámetro máx.: $58 \mathrm{~cm}$; diámetro boca: $48 \mathrm{~cm}$.

Presenta sello en el interior de una cartela, de 3,5 x $6,5 \mathrm{~cm}$. El sello se sitúa en el borde del mortero, dispuesto en diagonal y con lectura del exterior al interior de la pieza. Se aprecia parte de la corona que se sitúa en el lado izquierdo de la cartela. Las letras de la línea 1 miden $1,1 \mathrm{~cm}$ y de la segunda línea, $1 \mathrm{~cm}$. El sello corresponde al punzón 27.27 de la clasificación de Pallecchi $(2002,210)$.

El texto dice:

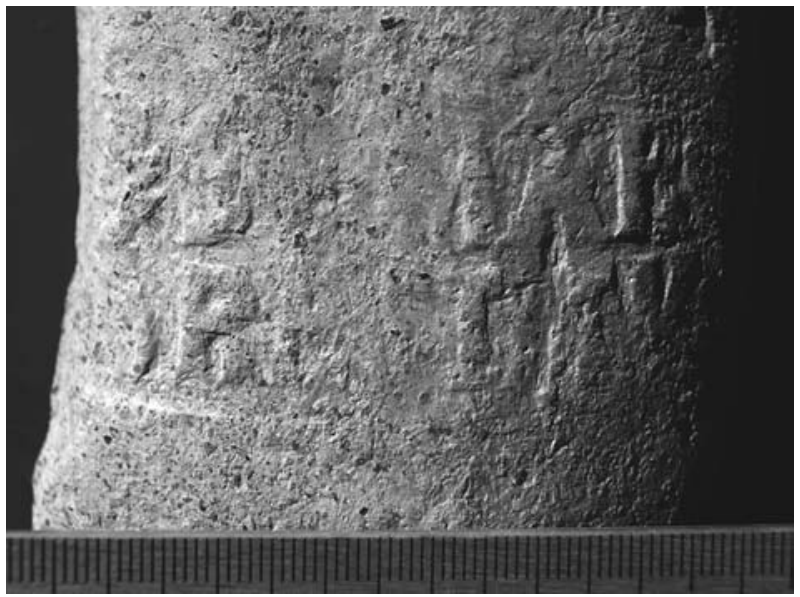

$S[T](a t i) \operatorname{MAR}(c i)$

RESTITV(ti)

Cronología: fin de época de Claudio-época flavia / inicios época antonina.

30. Circo. Campaña 2005. UE 9297, $\mathrm{n}^{\mathrm{o}} .110\left(\mathrm{n}^{\mathrm{o}}\right.$. de inv.: 137390). Nivel de destrucción del graderío sur del circo, fechado en época tardo-romana.

Forma Dramont D 2, fase 3. Borde de mortero con gran ala de tipo ganchudo. Presenta una estría poco marcada en el borde interior y restos de abrasivo arenoso en la cara interior de las paredes compuesto por granos rojizos y negros brillantes. Pasta rosada pálida muy fina, de tacto untuoso. Se aprecian partículas de mica dorada y de chamota usados como desgrasante. Diámetro máx.: $36,5 \mathrm{~cm}$; diámetro boca: $26 \mathrm{~cm}$.

Cronología: fin de época de Claudio-época flavia / inicios época antonina. 
31. Circo. Campaña 2006. UE $9450, n^{\circ} .43$ (n ${ }^{\circ}$. de inv.: 147089). Relleno de nivelación de la arena del circo, que presenta materiales cerámicos fechados entre la segunda mitad siglo I o inicios II d. C., excavado en el área de la necrópolis de incineración situada bajo este edificio.

Forma Dramont D 2, fase 3. Fragmento de borde de mortero con ala colgante desarrollada e inicio de la pared, de desarrollo hemisférico. Conserva restos de abrasivo arenoso en la cara interna del vaso compuesto por granos rojos, blancos y negros brillantes. Pasta áspera de color marrón rojizo con desgrasante arenoso y partículas de mica dorada. Diámetro máx.: $31,5 \mathrm{~cm}$; diámetro boca: $23 \mathrm{~cm}$.

Cronología: fin de época de Claudio-época flavia / inicios época antonina.

32. Tumba Monumental. Campaña 2008. UE 12158, $\mathrm{n}^{\circ} .73\left(\mathrm{n}^{\circ}\right.$. de inv.: 181473). Nivel de tierra de color grisáceo y de textura arenosa al exterior del costado norte del monumento funerario, interpretado como sucesivas deposiciones aluviales procedentes de crecidas del arroyo del Yuncal. Su cronología se sitúa entre finales del siglo I y la primera mitad del II d. C. (Cebrián, 2010).

Forma Dramont D 2, fase 3. Fragmento de borde de mortero con ala desarrollada colgante. Conserva indicios de una estría en el borde interno y restos de abrasivo arenoso con granos dorados, rojizos y negros en la cara interior. Pasta de color rosado muy fina con abundante desgrasante dorado. Diámetro máx.: $29 \mathrm{~cm}$; diámetro boca: $22 \mathrm{~cm}$.

Cronología: fin de época de Claudio-época flavia / inicios época antonina.

33. Plaza entre teatro y decumanus maximus. Campaña 2009. UE 13292, $\mathrm{n}^{\circ} .159$ ( $\mathrm{n}^{\circ}$. de inv.: 180382). Nivel de derrumbe de la vivienda visigoda localizada en el extremo occidental de la plaza, fechado en época medieval cristiana (Abascal, Alberola, Cebrián y Hortelano 2010, 57-58).

Forma Dramont D 2, fase 3. Fragmento de borde y pared de mortero con gran ala colgante, estría en la parte superior que marca el inicio del vaso y cuerpo de desarrollo hemisférico. Conserva abundante abrasivo arenoso en la pared interna. Arcilla de color rosa pálido, suave al tacto, con chamota y desgrasante compuesto por diminutas partículas brillantes. Diámetro máx.: $45,1 \mathrm{~cm}$; diámetro boca: $35 \mathrm{~cm}$.

Cronología: fin de época de Claudio-época flavia / inicios época antonina.

34. Viviendas cesarianas en la terraza superior a la basílica del foro. Campaña 2010. UE 14021, $\mathrm{n}^{\circ} .18$ (n . de inv.: 192185). Relleno conformado por abundantes piedras de pequeño tamaño procedentes de la disgregación de las paredes de una cisterna de una vivienda romana reutilizada hasta época andalusí como lugar de habitación. La UE 14021 se fecha en época medieval cristiana.

Forma Dramont D 2, fase 3. Borde de mortero con gran ala ganchuda y arranque del cuerpo de forma hemisférica. Presenta una estría bastante marcada en el extremo superior interno del recipiente, marcando el inicio del vaso. Arcilla fina de color anaranjado, bastante depurada. Superficie alisada de color beige rojizo. Desgrasante compuesto por partículas negras, doradas y chamota. Diámetro máx.: 49,1 cm; diámetro boca: $39 \mathrm{~cm}$.

Cronología: fin de época de Claudio-época flavia / inicios época antonina.

35. Viviendas cesarianas en la terraza superior a la basílica del foro. Campaña 2010. UE 14196, $\mathrm{n}^{\circ} .1$ ( $\mathrm{n}^{\mathrm{o}}$. de inv.: 184398). Relleno de una fosa de época tardo-romana.

Forma Dramont D 1. Borde de mortero con ala exvasada ganchuda y reborde vertical en la parte superior del recipiente. Presenta en su cara interna un abundante abrasivo arenoso bastante fino compuesto por granos rojizos, blancos, negros y dorados. Pasta de color rosado muy fina, untuosa al tacto con escaso desgrasante brillante. Diámetro máx.: $32,8 \mathrm{~cm}$; diámetro boca: $25 \mathrm{~cm}$.

Cronología: finales del siglo I a. C. / siglo I d. C.

36. Viviendas cesarianas en la terraza superior a la basílica del foro. Campaña 2010. UE 14210, $\mathrm{n}^{\circ} .119$ ( $\mathrm{n}^{\circ}$. de inv.: 195045). Vertido de nivelación que amortiza las viviendas cesarianas fechado entre finales del siglo I e inicios del II d. C. Entre el material cerámico recuperado en la UE 14210 se encuentra un borde Drag. 15/17 de terra sigillata hispánica, un fragmento sin forma de cerámica pintada con características técnicas y decorativas propias de finales del siglo I d.C. o inicios del II. También se recuperó un borde de ánfora Dressel 2/4 de mediados del siglo I d.C. Entre los materiales residuales se identificaron producciones de terra sigillata itálica y gálica, cerámica de paredes finas, dos fragmentos de lucerna de volutas y numerosos fragmentos de cerámica pintada.

Forma Dramont D 1. Fragmento de borde, cuerpo y base de mortero con gran ala algo colgante, grueso, reborde vertical en la parte superior del vaso, cuerpo de desarrollo hemisférico y arranque de base anular. Presenta abundante abrasivo de tipo arenoso, con partículas rojizas, negruzcas y brillantes, en la pared interna. Pasta muy fina y depurada de color rosado rojizo, algo untuosa. Desgrasante brillante poco apreciable. Diámetro máx.: $40 \mathrm{~cm}$; diámetro boca: $30 \mathrm{~cm}$.

Cronología: finales del siglo I a. C. / siglo I d. C.

37. Viviendas cesarianas en la terraza superior a la basílica del foro. Campaña 2010. UE 14227, ${ }^{\circ} .121\left(n^{\circ}\right.$. de inv.: 186715). Relleno de una fosa de expolio de época visigoda. 
Forma Dramont D 2. Fragmento de pico de mortero prácticamente horizontal del que sólo se conserva parte de un lateral rectilíneo. Pasta muy fina y depurada de color rosado y engobe beige claro. Desgrasante inapreciable. Diámetro indeterminado.

Cronología: siglo I d. C.

38. Viviendas cesarianas en la terraza superior a la basílica del foro. Campaña 2010. UE 14310, $\mathrm{n}^{\circ} .260$ ( $\mathrm{n}^{\circ}$. de inv.: 188530). Relleno de nivelación de las estructuras domésticas localizadas al este de la basílica, fechado en época de Tiberio por la presencia de formas de terra sigillata de producción itálica (Conspectus R.2, R.4, R.9.3, 7, 8, 13, 14, 17, 19, 33, 33.2, 38), vasos de paredes finas (Mayet XVIII, XXX, XXXV, XXXVI), cerámica pintada de producción local, un fragmento de ánfora Dressel 1C, una lucerna del tipo Deneuve IV y rojo pompeyano. En este mismo nivel se recuperaron algunos fragmentos residuales de cronología algo más antigua (barnices negros, paredes finas republicanas, cerámicas pintadas) como corresponde a vertidos compuestos por materiales procedentes de demoliciones de estructuras anteriores.

Forma Dramont D 2. Gran ala colgante de mortero de perfil ganchudo con reborde en la zona superior que marca el inicio del recipiente. Prácticamente no se conserva pared interior, por lo que es imposible determinar la existencia de abrasivo interno. Arcilla fina de color rosado oscuro con partículas doradas y blancas como desgrasante. Superficie áspera. Diámetro boca: $39 \mathrm{~cm}$.

39. Viviendas cesarianas en la terraza superior a la basílica del foro. Campaña 2010. UE 14311, nº 29 $\left(\mathrm{n}^{\circ}\right.$. de inv.: 187572). Relleno de un silo de época andalusí.

Forma Dramont D 1. Fragmento de borde de mortero con ala y grueso reborde vertical en la zona superior. Restos escasos de abrasivo en la cara interior de la pared. Arcilla de color rojizo muy depurada con desgrasante inapreciable. Diámetro máx.: $32,40 \mathrm{~cm}$; diámetro boca: $24 \mathrm{~cm}$.

Cronología: finales del siglo I a. C. / siglo I d. C.

40. Hallazgo antiguo. Sin procedencia $\left(\mathrm{n}^{\mathrm{o}}\right.$. de inv.: 195046).

Forma Dramont D 1. Fragmento de borde y cuerpo de mortero con ala colgante poco desarrollada, reborde en el extremo superior del vaso y pared hemisférica bastante abierta. Conserva en la cara interna abrasivo arenoso compuesto por granos rojos, negros y dorados, más desgastado hacia el fondo de la pieza. Se aprecia una perforación en el ala para el lañado de la pieza. La pasta es fina y muy depurada de tacto untuoso y color rosado, con la superficie algo más pálida. Desgrasante prácticamente inapreciable. Diámetro máx.: $53,5 \mathrm{~cm}$; diámetro boca: $46 \mathrm{~cm}$.

Cronología: finales del siglo I a. C. / siglo I d. C.

\section{LA EPIGRAFÍA. LOS SELLOS DE LOS MOR- TEROS}

La fabricación de morteros tuvo un carácter secundario dentro de la producción de officinae centroitálicas dedicadas a la industria de tejas y ladrillos para el abastecimiento de Roma.

Las estampillas sobre morteros indican el nombre del propietario de la figlina, en la mayoría de los casos perteneciente al orden senatorial, o el de la officina donde se había fabricado el mortero, junto al del artesano, que lo elaboró, en muchas ocasiones de condición social servil.

Los sellos de los morteros Dramont D 2 hallados en Segobriga revelan un origen desde la figlina Marciana y las officinae de la gens Domitia situadas en el entorno inmediato de Roma y en el territorio que abarca el área navegable del río Tíber y sus afluentes (Fig. 3).

Entre los grandes propietarios de figlinae se encuentran los Domitii. Varios miembros de esta familia pertenecieron al orden senatorial, entre ellos $C n$. Domitius Afer, cónsul en el 39 d. C., cuyos nombres aparecen sobre sellos de morteros, tégulas y ladrillos. La gens Domitia se convirtió con el paso del tiempo en la familia más importante en la producción latericia, que pasará a propiedad imperial con Marco Aurelio, heredada de su madre Domitia Lucilla ${ }^{1}$.

El taller de Cn(aeus) Domitius asociado al liberto Salutarus ( $\mathrm{n}^{\circ} .3$ del catálogo) se fecha circa el $75 \mathrm{~d}$. C., pues su nombre se encuentra en un sello de la obra latericia del anfiteatro flavio (CIL XV, 1093.2 = Bloch 499.2). A Salutarus lo encontramos en Roma (CIL XV, 1093.1 = Bloch 499.1; CIL XV, 1093.3 = Bloch 499.3 y CIL XV 1093.6 = Bloch, 499.6), en Pompeya (CIL $\mathrm{X}, 8048.17)$, Nemus (CIL XV, 1093.4), Bononia (CIL XV, 1093.5) y en Carthago (CIL VIII, 22636.2).

Es la primera vez que se documenta a Salutarus sobre sellos hallados en morteros centroitálicos en Hispania.

Priscus, es otro de los esclavos de la gens Domitia documentado en Segobriga $\left(\mathrm{n}^{\circ} .2\right.$ del catálogo). Este personaje fue esclavo de Cn. Domitius Afer (Dressel, 1891, 268). En el sello con mención a Priscus le sigue duorum Domitiorum. Sabemos que estos dos Domitii son Cn. Domitius Lucanus y Cn. Domitius Tullus para los que pasó a trabajar a la muerte de su dueño en el 59 d. C. De esta manera, se documenta en un sello sobre dolium de Roma (CIL XV, 2485) y en dos morteros de Pompeya (Bloch, 493).

La gens Calpetana es otra de las familias importantes en la producción latericia de Roma (Aguarod, 1991, 166-167). Caius Calpetanus Favor, mencionado en uno de los sellos hallados en Segobriga $\left(\mathrm{n}^{\circ} .6\right.$ del

1. Sobre las relaciones familiares de los miembros de la gens Domitia mencionada en los sellos sobre dolia, ladrillos y morteros, véase Dressel, 1891, 267-275. 

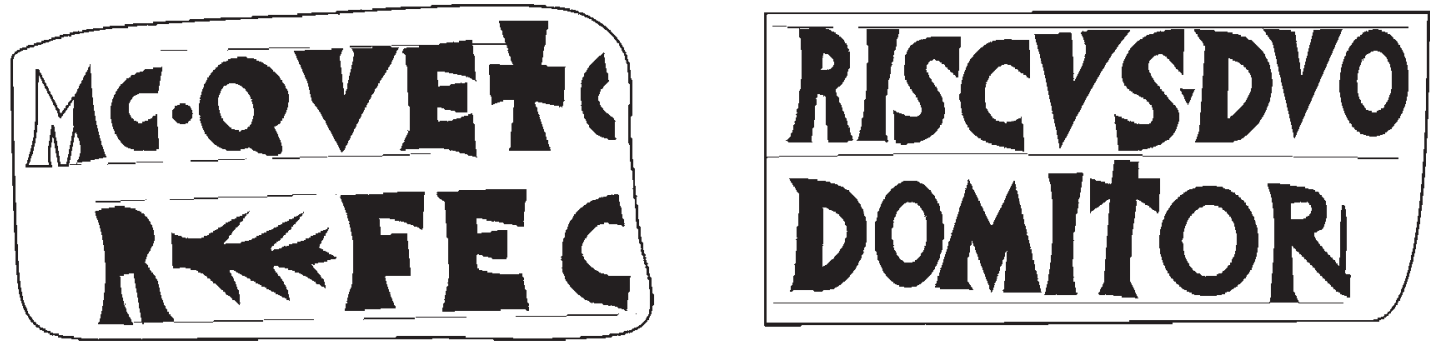

1
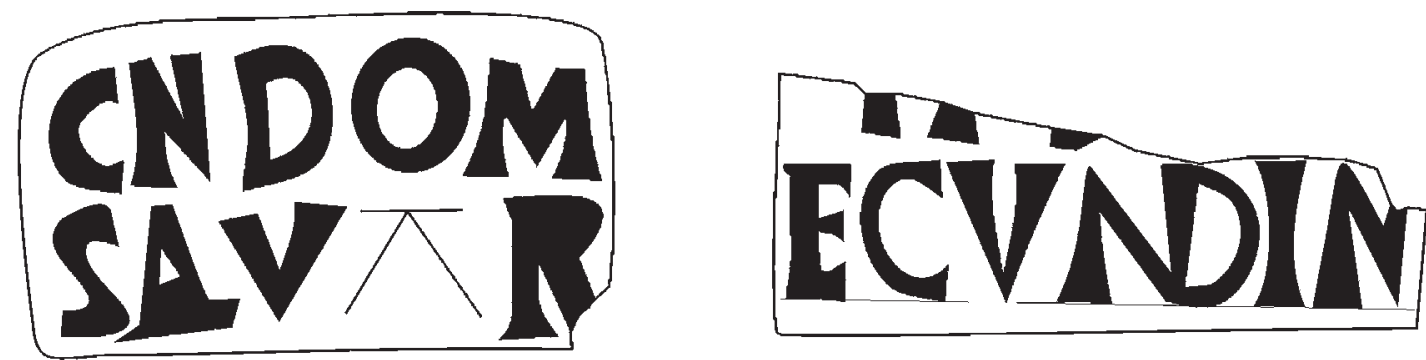

3
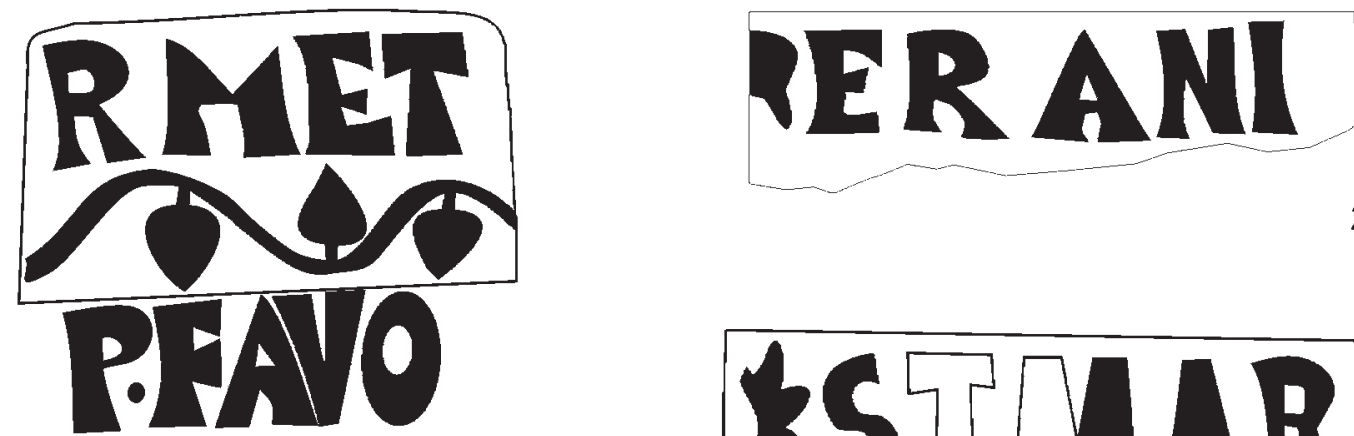

6

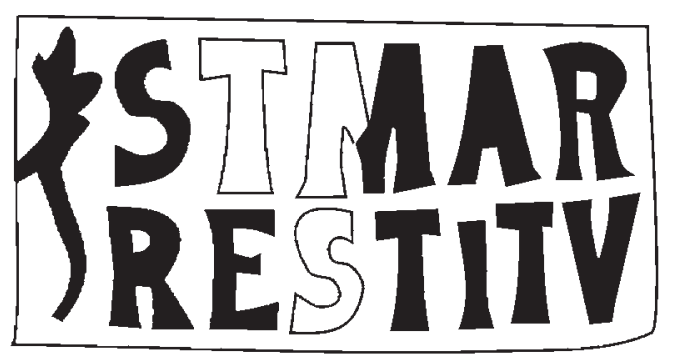

Figura 3: Dibujo de los sellos de los morteros centroitálicos hallados en Segobriga. El número de la pieza corresponde al del catálogo.

catálogo), aparece como officinator en época de Trajano de la figlina Marciana, propiedad en esa fecha del emperador (Dressel, 1891, 91). Dentro de las figlinae Marcianae trabajarán también los Statii Marcii, mencionados en otros sellos sobre mortero de Segobriga.

Uno de los esclavos de Caius Calpetanus Favor fue Hermes, que consiguió la manumisión en los primeros años del siglo II d. C. Mencionado como Caius Calpetanus Hermes aparece en varias estampillas como officinator en Roma en 123 d. C. (CIL XV, 318.1 a 4; 319, 320.1 a 2). En Hispania, se documenta en un sello sobre tégula en Mataró (Rico, 1995a, 212, fig. 5.5) y en otro hallado en Cambrils, Tarragona (Gorostidi, 2010, 197, no 160).

C. Calpetanus Favor se retiró en tiempos de Adriano hacia el 123 d. C. (CIL XV, 317), sustituyéndole Hermes al frente de la oficina.

Existe un paralelo para el sello de Segobriga en Hispania en el yacimiento del Camp de la Gruta (Torroella de Montgrí, Girona) sobre un mortero Dramont D 2 (Rocas y Roviras 1995, 171-173, nº. 2) fechado en la segunda mitad del siglo I d. C. 
Los Statii Marcii trabajaron, como ya hemos comentado, en la figlina Marciana, establecida hacia el 30 d. C. Su actividad se sitúa principalmente en el siglo I d. C. y sólo tres officinatores continúan en el siglo II (Aguarod 1991, 169-170). En dos sellos sobre morteros de Segobriga se menciona a dos personas vinculadas con esta familia. La primera de ellas es el esclavo Quietius ( $\mathrm{n}^{\mathrm{o}} .1$ del catálogo) y la segunda el liberto Restitutus (nº. 29 del catálogo). Quietius fue esclavo de Statius Marcius Celer, que trabajó con anterioridad al 79 d. C., pues contamos con dos sellos sobre mortero en el que se menciona a ambos en Pompeya (CIL X, 8048.35 y Bloch, 516). Su nombre aparece también en un sello sobre mortero hallado en la villa de Veïnat del Sant Crist (Cabrils, Barcelona), del que sólo se conserva el nombre Quie[tius] (Aguarod, 1991, 170).

Por su parte, Statius Marcius Restitutus está documentado en una estampilla sobre mortero en Pompeya (Bloch, 523) y en Roma (CIL XV, 1285). En una ocasión, su nombre aparece junto a uno de sus esclavos Albanus (Bloch 524, de Pompeya) y en otra junto a Lucifer (Bloch 525, de Pompeya), aunque en este último caso se ha podido demostrar que no hay relación con Restitutus (Aguarod, 1991, 157).

El nombre Secundinus aparece en un sello, que presenta completa la segunda línea ( $\mathrm{n}^{\circ} .5$ del catálogo). En la primera línea sólo se conservan los trazos inferiores de las dos primeras letras, que creemos podría restituirse como $M$ (arcus) Marius. Su actividad se desarrolla, con seguridad, antes de la destrucción de Pompeya en el 79 d. C., ya que contamos con varios sellos procedentes de la ciudad (Bloch 532a; Bloch 532b; CIL X, 8048.25a, b, c y d).

Por último, uno de los sellos hallados en Segobriga ( $\mathrm{n}^{\circ} .23$ del catálogo) conserva una única línea de texto en la que leemos Quintus Eranius, pero no hemos encontrado ningún paralelo para esta marca.

Junto a las estampillas halladas en las excavaciones arqueológicas realizadas en la ciudad, conocemos otra procedente de la villa de La Peña II situada al noreste de Segobriga a unos $4 \mathrm{~km}$ de distancia, que fue excavada en el año 2009 (Almeida, López y Morín 2010) 2 .

De ella, procede un mortero Dramont D 2, fase 3, que conserva la vertedera completa y dos sellos dispuestos a ambos lados de ésta. La estampilla del lado derecho es divergente respecto a la vertedera y su lectura se efectúa del interior al exterior, mientras la de la izquierda es convergente y se lee de igual modo que la anterior.

En el sello situado en el lado izquierdo de la vertedera se menciona en genitivo al officinator, Q(uintus)

\footnotetext{
2. Agradecemos a J. Morín y a los arqueólogos que realizaron la excavación de la villa de La Peña II (Saelices, Cuenca) la información facilitada, que está recogida en la memoria final de la intervención arqueológica presentada a la Consejería de Cultura de la Junta de Comunidades. Nosotros no hemos visto la pieza.
}

Oppius Natalis, vinculado a una de las familias que participó activamente en la producción de opus doliare de Roma (CIL XV, 1345.1 a 3; CIL XV, 1346.1 a 46), asociado a la figlina de Licinianis, propiedad de Domitia Lucilla maior, hacia el 120 d. C. No conocíamos hasta la fecha a ninguno de los artesanos que trabajó con este officinator, por lo que Rimiger mencionado en el sello del lado derecho de la vertedera del mortero hallado en el territorio de Segobriga se convierte en el primero. El texto completo de esta marca dispuesto en dos líneas es Rimiger / fecit.

\section{A MODO DE CONCLUSIÓN}

Las figlinae dedicadas a la fabricación de materiales de construcción, que estuvieron en actividad durante los dos primeros siglos del Imperio en el entorno de Roma, llevaron a cabo la exportación de sus productos en las provincias mediterráneas como mercancía de retorno en los barcos que regresaban a sus puertos de origen tras haber descargado, sobre todo, vino, grano $\mathrm{y}$ aceite en el puerto de Ostia.

La dispersión de los sellos de officinae itálicas sobre material latericio en la Tarraconense evidencia este comercio a partir de época flavia y durante el siglo II, con una mayor difusión en época de Trajano-Adriano (Rico, 1995b, 789-790).

Las importaciones de materiales constructivos en Segobriga están ausentes. Las marcas de alfareros documentadas sobre tégulas en la ciudad evidencian una producción en manos de la población indígena (Abascal, Cebrián y Riquelme 2000, 187-197; Cebrián, 2009, 169-182). Lo mismo sucede con la producción de dolia, que fue una actividad dispersa en la que intervinieron numerosos hornos artesanales.

Los morteros centroitálicos Dramont D 1 documentados en Segobriga se asocian a otras importaciones itálicas de cerámica de cocina, como cazuelas de rojo pompeyano y tapaderas, forma Vegas 16, y aunque el material anfórico es escaso, se encuentran en este mismo momento ánforas vinarias de la Tarraconense, formas Dressel 2/4 y Oberaden 74 y, por tanto, en un marco cronológico de la primera mitad del siglo I d. C. Aunque el conjunto más numeroso de los morteros centroitálicos corresponde a la forma Dramont D 2 que llegan a la ciudad a partir de época flavia.

La distribución de este tipo de recipiente en Hispania se constata a lo largo de toda la costa mediterránea, sobre todo, en el área catalana y en ciudades del interior peninsular a través de la ruta fluvial del Ebro, como Celsa, Caesaraugusta y Calagurris (Aguarod, $1991,179)$. Su presencia en un número elevado en Segobriga evidencia una ruta comercial terrestre desde el puerto de Carthago Nova, activa desde las primeras décadas del siglo I d. C. para la exportación del lapis specularis. Por esa vía llegaron los mármoles procedentes de canteras imperiales para el revestimiento arquitectónico del foro (Alvárez, Cebrián y Rodá 
2008, 101-120) y los ciclos estatuarios vinculados a la familia imperial de época julio-claudia realizados en marmor de Luni, Paros, Thasos y monte Pentélico (Noguera, Abascal y Cebrián, 2008, 283-343).

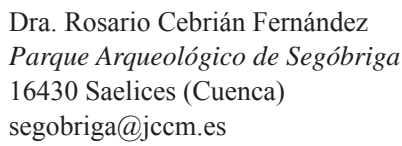

\section{BIBLIOGRAFÍA}

Abascal, J. M., Alberola, A., Cebrián, R. y HortelaNO, I., 2010: Segóbriga 2009. Resumen de las intervenciones arqueológicas, Cuenca.

Abascal, J. M., CEBriÁn, R. y RiQuelme, T., 2000: «Retucenus Elocum, Turanus, Antirus y la producción de tegulae en Segobriga», Anales de Prehistoria y Arqueología, 16, 2003, 187-197.

ABASCAL, J. M. y CEBRIÁN, R. 2007: „Carthago Nova como caput viae. Dos miliarios de Huelves (Hispania citerior)«, Zeitschrift für Payrologie und Epigraphik, 162, 257-262.

Aguarod Otal, C., 1991: Cerámica romana importada de cocina en la Tarraconense, Zaragoza.

AlarCão, J. DE, 1976: Fouilles de Conimbriga, VI. Céramiques diverses et verres, Paris.

AlCORTA IRASTORZA, E. J., 1995: «Sobre un mortarium sellado procedente de Lucus Augusti», Actas del XXIII Congreso Nacional de Arqueología, II, 289-295, 1993 , Vigo.

Almagro BASCH, M., 1952: Las inscripciones Ampuritanas griegas, ibéricas y latinas, Monografías Ampuritanas, 11, Barcelona.

Almagro-GorbeA, M. y LoRrio, A. J. 1989: Segobriga III. La muralla norte y la puerta principal, Cuenca.

AlmeidA, R. R. DE, LÓPEZ, F. y MoRín, J., 2010: «La Peña II (Saelices, Cuenca). Una unidad de transformación rural en el territorio de Segobriga», Preactas del Coloquio Internacional De vino et oleo Hispaniae. Áreas de producción y procesos tecnológicos del vino y del aceite en la Hispania romana, 123-124, Murcia.

Álvarez, A., CEBrián, R. y RodÁ, I., 2008: «El mármol de Almadén de la Plata y los marmora importados del foro de Segóbriga», en T. Nogales y J. BELTRÁN FORTES (eds.), Marmora hispana: explotación y uso de los materiales pétreos en la Hispania Romana, 101-120, Roma.

Aquilué, X., Mar. R., Nolla, J.M., Ruíz de Arbulo, J. y SANMARTÍ, E., 1984: El fòrum romà d'Empúries (Excavacions de l'any 1982). Una aproximació arqueològica al procés històric de la romanització al nord-est de la Península Ibèrica, Monografies Emporitanes VI, Barcelona.

ArraudA, A. M. y Viegas, C., 2004: «Les mortiers de l'Alcáçova de Santarém (Portugal)», Société Française
d'Étude de la Céramique Antique en Gaule, Actes du Congrès de Vallauris, 341-349.

BALIL, A., 1982: «Notas de arqueología palentina». Publicaciones de la Institución Tello Téllez de Meneses, 46, 109-111, Palencia.

BLOCH, H., 1967: The roman brick-stamps not published in volume XV, 1 of the Corpus Inscriptionum Latinarum, Roma.

Cebrián, R., 2009: «La producción latericia en Segobriga. Nuevos hallazgos (2002-2009)», Lucentum, XXVIII, 169-182.

CeBrián, R., 2010 «La denominada Tumba Monumental de Segobriga (Saelices, Cuenca). Un mausoleo en forma de altar», Lucentum, XXIX, 139-148.

DRESSEL, H., 1891: CIL XV. Inscriptiones urbis Romae Latinae. Instrumentum domesticum, Pars. 1, Berlín.

FERNÁNDEZ IZQUiERDO, A., 1980: «Estudio de los restos arqueológicos submarinos en las costas de Castellón», Cuadernos de Prehistoria y Arqueología Castellonenses, 7, 135-196.

GoRostidi, D., 2010: Ager Tarraconensis 3. Les inscripcions romanes, Documenta 16, Tarragona.

GARCÍA Y BELlido, A., 1963: «Parerga de arqueología y epigrafía hispano-romana (II)», Archivo Español de Arqueología, 107-108, 191-206.

HARTLEY, F., 1973a: «The marketing and distribution of mortaria», Current research in Romano-British coarse pottery: papers given at a C.B.A. Conference held at New College, March 24 to 26, 1972, ed. A. Detsicas, Research reports/Council for British Archaeology, 10, Council for British Archaeology, 35-91, Oxford.

HARTLEY, F., 1973b: «La diffusion des mortiers, tuiles et autres produits en provenance des fabriques italiennes». Cahiers d'archéologie subaquatique, II, 51-57.

Hevia GonZÁlez, S. Y MoNTES LóPEZ, R., 2009a: «Cerámica Romana Altoimperial de fabricación regional del Chao Samartín (Grandas de Salime, Asturias)», Cuadernos de Prehistoria y Arqueología, 35, 27-190.

Hevia GonzÁlez, S. y Montes LóPez, R., 2009b: «Cerámica común del siglo $\mathrm{I} d$. C. en el castro del Chao Samartín (Grandas de Salime, Asturias). Notas sobre el repertorio en un ambiente militarizado», en Á. MoRILLO CERdÁn y N. HANEl (eds.), Limes $X X$. XX Congreso Internacional de Estudios sobre la frontera romana, II. Anejos de Gladius, 13, 639-654, Madrid.

JONCHERAY, J. P., 1972: «Contribution a l'étude de l'épave Dramont D, dite 'des pelvis'», Cahier d'archéologie subaquatique, 1, Antibes.

JONCHERAY, J. P., 1973: «Contribution a l'étude de l'épave Dramont D, dite 'des pelvis'», Cahier d'archéologie subaquatique, 2, Antibes.

JONCHERAY, J. P., 1974: «Étude de l'épave Dramont D, dite 'des pelvis'», Cahier d'archéologie subaquatique, 3, Antibes.

Luezas Pascual, R. A., 1988: «Avance al estudio de la cerámica común romana en la Rioja», Berceo, 114-115, 51-60.

Luezas Pascual, R. A., 2001: «Cerámicas comunes de importación de época romana en el Municipium 
Calagurris Iulia (Calahorra, La Rioja)», Kalakorikos, 6, 71-100.

MARTínEZ-SÁIZ, A., 1977: «Materiales para un índice de marcas de ceramista en Mortaria romanos», Studia Archaeológica, 44, 149-180.

NoguerA, J. M., ABASCAL, J. M. Y CEBRIÁN, R., 2008: «El programa escultórico del foro de Segobriga», en T. NoGALES y J. CONDE (eds.), Escultura Romana en Hispania. V, 283-343, Murcia.

NIETO, X. ET ALII, 1989: Excavacions arqueològiques subaquàtiques a Cala Culip, vol. I, Girona.

PALLECCHI, S., 2002: I mortaria di produzione centro-italica. Corpus dei bolli, Roma.

PÉrez GonZÁlez, C. y FERnÁNDEZ IBÁÑEZ, C., 1989: «Sellos de alfarero sobre Mortaria en la Península Ibérica», Publicaciones de la Institución Tello Téllez de Meneses, 60, 67-98.

RAMOS FOlQUÉS, A., 1974: «Morteros de la Alcudia de Elche», Miscelánea Arqueológica, II, XXV Aniversario de los cursos de Ampurias (1947-1971), 270, Barcelona.

RAmos J., WAgner J. y FERnÁNDEZ A., 1984: «El yacimiento arqueológico submarino de Ben-Afelí. Estudio de los materiales (Almazora, Castellón)», Cuadernos de Prehistoria y Arqueologia Castellonenses, 10, 149-158.
RIBAS BERTRÁN, M., 1972: «La villa romana de Torre Llauder», Noticiario Arqueológico Hispánico, 1, 115-180.

Rico, C., 1995a: «Index de les marques epigràfiques sobre tegulae romanes de Catalunya i el País Valencià (antiga Tarraconensis)», Saguntum, 28, 197-215.

RicO, C., 1995b: «La diffusion par mer des matériaux de construction en terre cuite: un aspect mal connu du commerce antique en Méditerranée occidentale», Mélanges de l'École Française de Rome. Antiquité, 107, n², 767-800.

Rocas I Gutiérrez, X. y Roviras I PADrós, A., 1991: «Contribució a l'estudi del jaciment del Camp de la Gruta (Torroella de Montgrí): els morters itàlics estampillats», Cypsela, IX, 169-175.

SABRIÉ, M., y SABRIÉ, R., 1981: «Les mortiers», en Y. SoLIER Et Alii, «Les épaves de Gruissan», Archaeonautica, 3, 88-94.

SÁNCHEZ SÁNCHEZ, M. Á., 1990: «Nuevos morteros sellados del tipo Cap Dramont 2 en España», Italica. Cuadernos de trabajos de la Escuela Española de Historia y Arqueología en Roma, 18, 117-133.

VEGAS, M., 1973: Cerámica común romana del Mediterráneo Occidental, Barcelona. 